\title{
Validation List no. 98 Validation of publication of new names and new
combinations previously effectively published
outside the IJSEM
}

Correspondence

Jean Euzéby

j.euzeby@envt.fr
The purpose of this announcement is to effect the valid publication of the following new names and new combinations under the procedure described in the Bacteriological Code (1990 Revision). Authors and other individuals wishing to have new names and/or combinations included in future lists should send three copies of the pertinent reprint or photocopies thereof to the IJSEM Editorial Office for confirmation that all of the other requirements for valid publication have been met. It is also a requirement of IJSEM and the ICSP that authors of new species, new subspecies and new combinations provide evidence that types are deposited in two recognized culture collections in two different countries (i.e. documents certifying deposition and availability of type strains). It should be noted that the date of valid publication of these new names and combinations is the date of publication of this list, not the date of the original publication of the names and combinations. The authors of the new names and combinations are as given below, and these authors' names will be included in the author index of the present issue and in the volume author index. Inclusion of a name on these lists validates the publication of the name and thereby makes it available in bacteriological nomenclature. The inclusion of a name on this list is not to be construed as taxonomic acceptance of the taxon to which the name is applied. Indeed, some of these names may, in time, be shown to be synonyms, or the organisms may be transferred to another genus, thus necessitating the creation of a new combination.

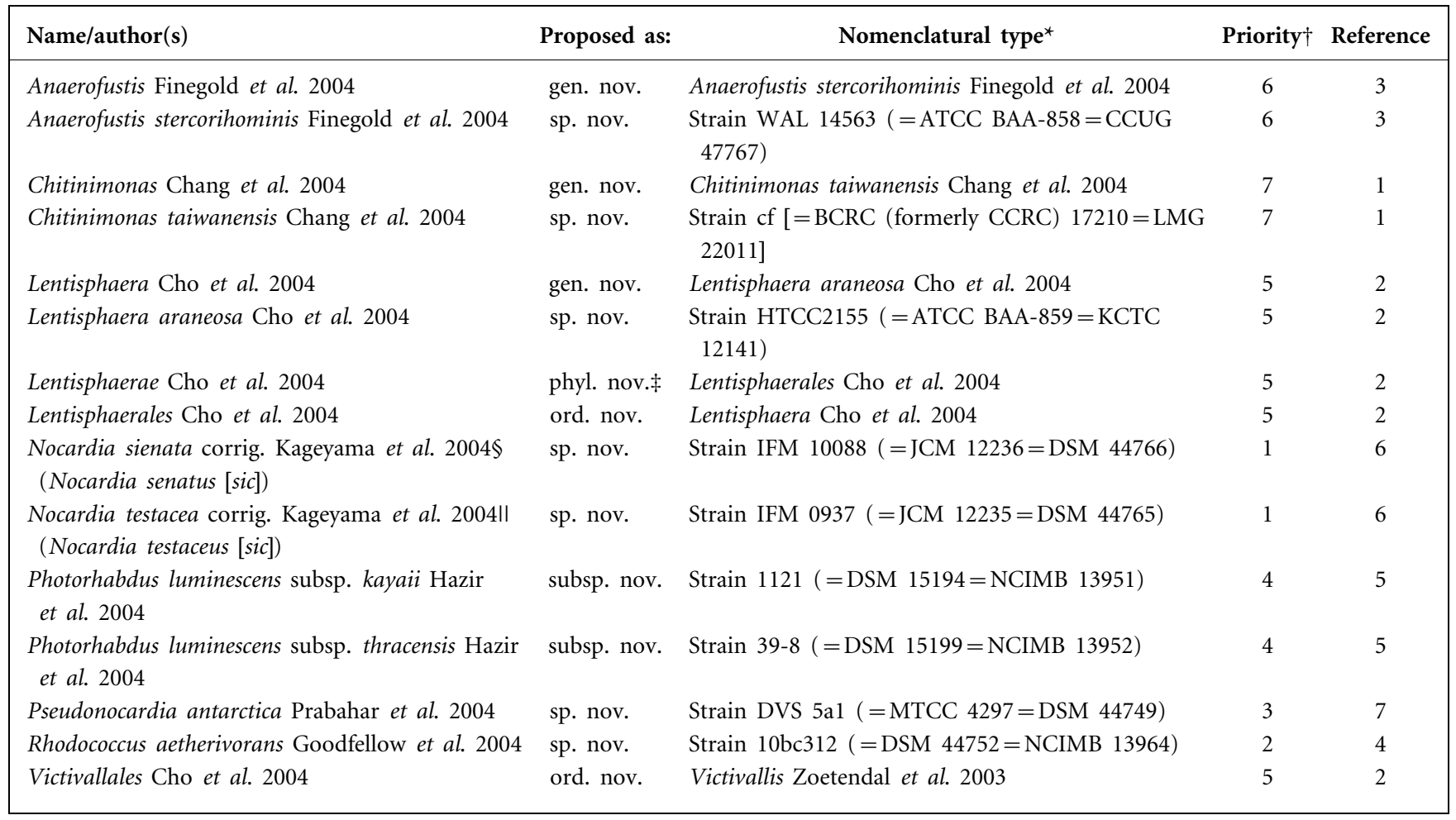


For references to Validation Lists 1-71, see Int J Syst Bacteriol 49 (1999) 1325. Lists 72-97 were published in Int J Syst Evol Microbiol 50 (2000) 3 , 423, 949, 1415, 1699, 1953; and 51 (2001) 1, 263, 793, 1229, 1619, 1945; and 52 (2002) 3, 685, 1075, 1437, 1915; and 53 (2003) 1, 373, 627, 935, 1219, 1701; and 54 (2004) 1, 307, 631.

*Abbreviations: ATCC, American Type Culture Collection, Manassas, VA, USA; BCRC, Bioresource Collection and Research Center, Food Industry Research and Development Institute, Hsinchu, Taiwan; CCUG, Culture Collection, University of Göteborg, Göteborg, Sweden; DSM, DSMZ - Deutsche Sammlung von Mikroorganismen und Zellkulturen, Braunschweig, Germany; IFM, Research Center for Pathogenic Fungi and Microbial Toxicoses, Chiba University, Chiba, Japan; JCM, Japan Collection of Microorganisms, RIKEN, Saitama, Japan; KCTC, Korean Collection for Type Cultures, Korea Research Institute of Bioscience \& Biotechnology, Yusong, Taejon, Republic of Korea; LMG, LMG Culture Collection, Universiteit Gent, Gent, Belgium; MTCC, Microbial Type Culture Collection \& Gene Bank, Institute of Microbial Technology, Chandigarh, India; NCIMB, National Collection of Industrial and Marine Bacteria, Aberdeen, UK.

$\dagger$ Priority number assigned according to the date the documentation and request for validation are received.

$\ddagger$ The name Lentisphaerae is listed for completeness. However, names above the rank of class are not covered by the Rules of the Bacteriological Code (1990 Revision) and the phylum Lentisphaerae is not to be regarded as having been validly published.

\$The specific epithet has been corrected on validation. In the effective publication, the etymology is as follows: N.L. gen. n. senatus referring to the colony colour of ochre-yellow of the Nocardia. However, the genitive noun senatus means of the Senate (the supreme council in Rome). Consequently, with the authors' agreement, the specific epithet has been changed to sienata (N.L. fem. adj. sienata sienna-coloured, referring to the colony colour of ochre-yellow of the Nocardia).

IIThe specific epithet has been corrected on validation.

\section{References}

1. Chang, S.-C., Wang, J.-T., Vandamme, P., Hwang, J.-H., Chang, P.-S. \& Chen, W.-M. (2004). Chitinimonas taiwanensis gen. nov., sp. nov., a novel chitinolytic bacterium isolated from a freshwater pond for shrimp culture. Syst Appl Microbiol 27, 43-49.

2. Cho, J.-C., Vergin, K. L., Morris, R. M. \& Giovannoni, S. J. (2004). Lentisphaera araneosa gen. nov., sp. nov, a transparent exopolymer producing marine bacterium, and the description of a novel bacterial phylum, Lentisphaerae. Environ Microbiol 6, 611-621.

3. Finegold, S. M., Lawson, P. A., Vaisanen, M.-L., Molitoris, D. R., Song, Y., Liu, C. \& Collins, M. D. (2004). Anaerofustis stercorihominis gen. nov., sp. nov., from human feces. Anaerobe 10, 41-45.

4. Goodfellow, M., Jones, A. L., Maldonado, L. A. \& Salanitro, J. (2004). Rhodococcus aetherivorans sp. nov., a new species that contains methyl t-butyl ether-degrading actinomycetes. Syst Appl Microbiol 27, 61-65.

5. Hazir, S., Stackebrandt, E., Lang, E., Schumann, P., Ehlers, R.-U. \& Keskin, N. (2004). Two new subspecies of Photorhabdus luminescens, isolated from Heterorhabditis bacteriophora (Nematoda: Heterorhabditidae): Photorhabdus luminescens subsp. kayaii subsp. nov. and Photorhabdus luminescens subsp. thracensis subsp. nov. Syst Appl Microbiol 27, 36-42.

6. Kageyama, A., Yazawa, K., Nishimura, K. \& Mikami, Y. (2004). Nocardia testaceus sp. nov. and Nocardia senatus sp. nov., isolated from patients in Japan. Microbiol Immunol 48, 271-276.

7. Prabahar, V., Dube, S., Reddy, G. S. N. \& Shivaji, S. (2004). Pseudonocardia antarctica sp. nov. an Actinomycetes from McMurdo Dry Valleys, Antarctica. Syst Appl Microbiol 27, 66-71. 